\title{
Brand Awareness Through Sports Sponsorship: Assessing Family Bank's Eldoret Half Marathon
}

\author{
Lilian Mulei Leah Muchemi (Dr.)* \\ School of Journalism and Mass Communication, University of Nairobi \\ P.O. box 310197-00100 Nairobi, Kenya
}

\begin{abstract}
The research is self-sponsored
Abstract

Sports sponsorship is increasingly becoming part of the major corporate activities. Scholars have recognized the central position taken by sports sponsorships in the corporate world. Busby and Digby (2012) posit that sports sponsorship wields transformative power that is capable of driving exponential growth in brand awareness and affinity; amassing the numbers and the connections needed for business success. Sports sponsors have a huge advantage over others in the corporate arena mainly stemming from the massive following sports games have (Gamble, 2011). Kenyans are reputed for their prowess in athletics especially long distance races and the marathon. Hence companies have come out to leverage on this potential with the knowledge that crowds will be attracted by the presence of world athletic champions in their events. Gambel (2011) notes that with just the right personnel, a brand's sales can soar up two times than the brand in the corporate sponsorship and that sports sponsorship impacts brands positively due to the powerful social media influence resulting in sporting activities and discussions. Commercial banks have increasingly used sponsorship of sporting activities to boost their corporate image with the intention of translating this into brand awareness. The objective of this paper is to find out the effect of sports sponsorship on the brand awareness of Family Bank Kenya. The study utilized the descriptive research design with questionnaires and interviews as the research methods. The study sample size consisted of 100 customers and 10 departmental heads from Family Bank branches in Eldoret. Systematic sampling and purposive sampling methods were used.
\end{abstract}

Keywords: Corporate, sports sponsorship, brand awareness, marathon, consumers/customers

DOI: $10.7176 / \mathrm{JMCR} / 77-05$

Publication date:March $31^{\text {st }} 2021$

\subsection{Background}

Classical public relations theory as articulated by Grunig (2006) holds that corporate entities undertake corporate sponsorship of social activities like sports as a persuasive tool to help target audiences learn new information about the sponsoring entities. In essence, corporate sponsorship is a covert public relations activity that should lead to tangible benefits for the sponsoring business (Kevin, 2013).

It is this expected benefit of competitive advantage that compels companies to sponsor social activities L'Etang (2013). For such activities with wide interest in the public, the sponsor who is allowed to display their logo, slogans and other associated brand aspects, stands to benefit from the high publicity associated among the general public that interacts with the event (Pickton \& Broderick, 2005). Common social areas that have potential to attract high levels of publicity include sports activities (Akwensivie, Narteh \& Iden, 2014).

\subsection{Half-Marathon races in Kenya}

Kenya is known globally as the hub of the best athletes in general and the marathon in particular. Through MagicalKenya, the country has invested in reputable marathon runners to market itself to the world as the best tourist destination (magicalkenya.com) Renowned Eliud Kipchoge, Brigit Kosgei and Ruth Chepngetich have participated in this campaign successfully. There are many annual half marathon races in Kenya such as Beyond Zero Half Marathon, Amazing Maasai marathon, Lewa marathon, Baringo half-marathon, Standard Chartered marathon and Family Bank Group Eldoret half marathon. Family bank is the sole sponsor of the Eldoret Half marathon. This corporate sports sponsorship event is the focus of this paper.

The Family Bank Eldoret Half Marathon is an annual event slated in the Athletics Kenya calendar for the first Sunday of every October. Family Bank started in 1984. According to Central Bank of Kenya, CBK (2018), Family Bank Limited (FBL), commonly known as Family Bank, is a medium-sized commercial bank in Kenya, It is licensed by the Central Bank of Kenya. It is the fifth-largest bank in Kenya by branch network. As of June 2016, the bank had 93 branches in Kenya and a customer base of over 1.8 million. As of 31 December 2015, the bank's total assets were valued at KSh81.3 billion (approx. US\$812.7 million), with shareholders' equity of KSh11.9 billion (approx. US\$119 million). It has been the sponsor of the annual Eldoret Half Marathon since 2007.

With a vision to transform the lives of the people in Africa, Family bank is known to support its publics "through innovative, efficient and reputable practices".(Familybank.com). One of those practices is sports 
sponsorship especially the Family Bank half marathon whose proceeds go to programs such as education and health. With the intense advertising and media visibility of this event, it is assumed that the bank achieves remarkable brand awareness among its customers. This is assumption is yet to be ascertained. Using this marathon as the case of focus, this study aimed at establishing the effect of sports sponsorship on brand awareness of Family Bank among its customers in Kenya.

\subsection{Corporate Sports Sponsorship}

Scholars such as Evans and Hansen (2013) assert that there is an emerging trend of studies that try to establish how brand awareness is affected by corporate sponsorship of sporting activities. Pricewaterhousecoopers-PWC (2010) as quoted in Reiser (2012), for instance reported that global sponsorship of sports stood at a staggering 29 billion US dollars as at the year 2000. This evidence lends credence to the realization that corporate sponsorship of sporting activities and corporate social responsibility has become a very dominant part of business efforts towards creating public awareness (Spais \& Johston, 2014).

Reiser (2012) asserts that sponsorship of sporting activities is an essential part of marketing in general and public relations in particular. Sponsorship is a way to introduce consumers to a company, product or service, and encourage a one-to-one relationship. It allows a company to do this by showing empathy with the sponsored sport (Pickton \& Broderick, 2005).

Sponsorship, in contrary to advertising, does not directly use the mass media to convey a specific message, but rather presents a possibility to represent a sport, club or event that gives prestige to the company through association (Reiser, 2012). It reaches the consumers who wish to watch that sport, club or attend the event. The association between the company and viewer also creates credibility, whereby the consumer is more likely to believe that the company and product have some kind of value (Schivinski \& Dabrowski, 2016). Amaoko, Kwasi, Dzogbenuku and Kwesie (2012) support the theoretical expectations of Grunig (2006) that corporate sponsorship should serve as a persuasive and communication tool to enhance product and corporate brand awareness. In Kenya, various companies have been involved in the financing of sports activities.

Servaes and Tamayo (2012) further provide evidence that the effect of corporate sponsorship on brand awareness may be influenced by the public reputation of the sponsoring firms. They reveal that the impact of corporate sponsorship will still be negative even if the level of awareness is high among customers if the related firm has a poor public reputation. In summary, the evidence from Servaes and Tamayo (2012) point out that the effect of corporate sponsorship is conditional on the level of awareness of the firm and the firm's corporate reputation in the public. The findings are supported by Grimaldi (2014) with respect to the sponsors of the European Champions League for football.

From a corporate sports sponsorship perspective, Makungu (2014) carried out a study to establish the effect of sports sponsorship on brand image and performance of Kenyan firms involved in sports. Using a descriptive survey and primary data based on a questionnaire, the study evaluated the separated effect of sports sponsorship among other variables on financial performance of 87 companies that engage in sports sponsorship in Kenya. The regression analysis results showed that sports sponsorship is instrumental in improving a company's brand image. This conclusion is supported by the study's finding that sports sponsorship enhances customer loyalty to the sponsoring firm. Other aspects that were positively impacted by sports sponsorship on the basis of Makungu (2014) include corporate reputation and demand for the products supplied by the sports sponsor.

Companies have faced more and more problems creating awareness in the consumer markets with their traditional marketing instruments, such as advertising and sales promotions. This is the reason why sponsorship has become increasingly popular as a public relations tool.

Companies are aware of the positive aspects of linking their brand with a sports celebrity or a sporting event to reach potential consumers, and therefore this has become very important at present. Furthermore, companies can differentiate themselves through sports sponsorship from other brands with a good sports sponsorship deal (Ukman, 2015).

Prominent marathon runners such as Nancy Jelagat and Daniel Zimiyu have attracted immense interest in Family Group Eldoret marathon. However it is not clear how Family Bank's sponsorship of the Eldoret Half Marathon affects its brand awareness. Given that Family Bank has been a consistent sole sponsor of the Eldoret Half Marathon and it will be interesting to find out how the sponsorship has affected its brand awareness.

In Jordan and Tomalieh (2016) carried out a study to establish the impact of events sponsorship on purchase intention of the attendees of the sponsored events. The study used brand image as a mediating variable. Brand awareness was taken as one of the independent variables besides the event-sponsor fit and the attitude of the attendee towards the event. The study used a total of 400 randomly distributed questionnaires. $96.75 \%$ was established as the response rate. The findings indicated that brand awareness has a strong positive effect on the purchase intention of event attendees. It also established that the other independent variables had a similar albeit weaker effect.

Kipruto (2014) carried out a study to find out the effect of corporate social responsibility on financial 
performance of commercial banks in Kenya. The study relied on secondary data over a five-year period spanning 2009 to 2013. Further, the study measured financial performance using earnings before taxes. The study used the actual spending on corporate social responsibility activities to measure expenditure on social activities. The study relied on a descriptive survey and analyzed data using multiple linear regression of financial performance on corporate social expenditure. The findings indicated that expenditure on social activities had a positive effect on financial performance of commercial banks in Kenya. This study therefore failed to capture the effect of sports sponsorship on brand awareness.

Njambi (2012) carried out a study to establish the effect of sponsorship of social activities at Kenya Airways. This case study analysis relied on both primary data and secondary data obtained from the company's financial statements. The findings indicated that the firm was actually involved in financing social activities with a focus on water, environment, health and education. The study employed content analysis in the analysis of the research data. It therefore failed to cover other types of companies particularly banks and the effect corporate sponsorship has on brand awareness.

\subsection{The social exchange theory}

Initially proposed by Thibaut and Kelly (1959) the Social Exchange Theory postulates that individuals take into account the consequences of their behavior before they act in a given way. It stipulates that consideration of costs and benefits of actions is instrumental in human decision making. Taken in context, this implies that corporate sponsors consider the effect of the sponsorship of social activities before they initiate the sponsorship programs. In line with this theory the economic benefits of corporate sports sponsorship must be high enough to cover the costs of the sponsorship.

The theory is rooted in the twin concepts of self-interest and interdependence (Lawler \& Thye, 1999). While corporate sponsors act in self-interest, they inevitably interdepend on the expected actions of consumers following brand awareness. Taken to its logical conclusion, social exchange theory anticipates a positive effect of corporate sponsorship of social activities on brand awareness. This is because in the context of the theory, the corporate sponsors act to maximize their economic benefits from the sponsorship activities. This view is supported by McDonell, Strom-Gottfried, Burton and Yaffe (2006) who indicate that people choose alternatives that offer the highest profits and rewards ceteris paribus. Although the theoretical postulation of the social exchange theory is plausible, it assumes that the firms are guided by rationality of maximizing the corporate welfare. It therefore ignores the behavioral bases that are likely to accrue when managers deviate from the rationality model of decision making.

Turban and Greening (1997) support this theoretical orientation by showing that indeed financing of social activities signals social attractiveness of the social responsible company and therefore greatly improves brand awareness. According to Turban and Greening(1997), the signals sent by the financing of social activities such as sports enhance competitive advantage over the firms that do not engage in social responsibility activities. The theory helps explain how sports sponsorship is expected to create brand awareness and therefore falls in the context of the study.

\subsection{Excellence Theory of Public Relations}

The excellence theory of public relations is a result of protracted study in the effective approach to public relations growing from the works of Cutlip and Center (1952), Grunig (1975) and Grunig (1992). Later contributions to the general theory have come from Grunig and Grunig $(2006,2008)$. The general essence of the theory is that the value of public relations to an organization derives from the organization itself and how it relates with its strategic publics. In essence, a good relationship with the public's is mutually beneficial to the organization and the public's given that it helps them achieve their respective goals, reduce the costs of negative publicity and increase income by providing desired goods and services.

In line with the theory, the value of public relations is optimized first by the identification of the strategic publics and then by subsequently building long term relationships through symmetrical communication programs. Sponsorship of social activities including sports can be seen from this light. It is expected that the public relations efforts through the sponsorship of the strategic sectors that patronized by the company customers, the company is bound improve its income streams by leveraging in this goodwill.

\subsection{Methodology}

This study adopted the mixed method research approach on collecting and analyzing data.. Quantitative data was therefore collected using a closed ended questionnaire to quantify the level of brand awareness among Family Bank customers. Qualitative data was collected using interview guides on the Heads of departments of the two selected branches of Family Bank.

Family Bank (2018) indicates on its website that it has over 1.7 million customers and that the number is rapidly growing. Family Bank has two branches in Eldoret namely; Eldoret Main Branch and Eldoret West 
Branch. This study therefore targeted customers from the two branches in Eldoret who are estimated to be over ten thousand according to Family Bank marketing department and 10 heads of departments from the two branches. A sample size of 100 customers was selected using Yamane Formula. Yamane (1967) provides a formula to calculate sample sizes at a 90 percent confidence level based on varied populations. This formula was used to calculate the sample size

$$
n=\frac{N}{1+N(e)^{2}}
$$

Where $\mathrm{n}$ is the sample size,

$\mathrm{N}$ is the population size,

$\mathrm{e}$ is the level of precision/ sampling error

$\mathrm{n}=10000 / 1+10000(0.10)^{2}$

$\mathrm{n}=100$

Ten heads of departments from the two branches of Family Bank in Eldoret were therefore selected and they included the branch manager, marketing manager, finance manager, operations manager and public relations manager. Systematic sampling method was used where every $5^{\text {th }}$ customer picking a ticket in the banking hall was chosen starting with a random customer. Purposive sampling was used which allowed the researcher to select a sample on the basis of his/her knowledge of the target population. The study therefore used Heads of departments who were deemed more conversant with the Marathon. This is based on their involvement in the marathon from the planning stage to the executing of the event.

\subsection{Research Results}

\subsection{Awareness of Family Bank Eldoret Half Marathon by customers}

The customers' awareness of Family Bank EHM was tested and the results revealed that the majority of respondents were fully aware of the event.

Table 1: customers'Awareness

\begin{tabular}{|c|c|c|}
\hline Extent of awareness & No & Distribution \\
\hline Not at all & 12 & 12 \\
\hline Barely aware & 7 & 7 \\
\hline Not sure & 8 & 8 \\
\hline Relatively aware & 15 & 15 \\
\hline Fully aware & 58 & 58 \\
\hline Total & $\mathbf{1 0 0}$ & $\mathbf{1 0 0}$ \\
\hline
\end{tabular}

Based on the study results in Table 4.1 above, it was established that that, majority $58 \%$ of the study respondents were fully aware of Family Bank Eldoret half-marathon 15\% were relatively aware, $12 \%$ were not aware at all, $8 \%$ of respondents were not sure while $7 \%$ indicated that they were barely aware of the Family Bank Eldoret half-marathon. The study results obtained may be an indication of the bank's consistence, having held the marathon within Eldoret town over the last three years. Interviewees on the other hand, expressed confidence in the communication strategies used to create awareness of the event among the communities at large and the bank's customers.

Table 2: Agreement to the Extent of Awareness of Family Bank Eldoret Half Marathon

\begin{tabular}{|l|l|l|}
\hline & Mean & Std deviation \\
\hline Eldoret Half Marathon helps create brand awareness of Family Bank & 3.69 & 0.39 \\
\hline The Eldoret Half Marathon is known to be a Family Bank event & 3.90 & 0.15 \\
\hline The Marathon helps increase the awareness of Family Bank & 3.59 & 1.25 \\
\hline $\begin{array}{l}\text { I understand the causes into which the funds raised from Eldoret Half Marathon are } \\
\text { put }\end{array}$ & 3.84 & 1.10 \\
\hline The bank displays the products and services they offer during the marathon & 3.31 & 0.95 \\
\hline Family Bank comes to mind when I hear of the Eldoret Half Marathon & 3.75 & 0.28 \\
\hline Family Bank uses advertising and promotional activities to support the Marathon & 3.76 & 0.31 \\
\hline Total & 25.84 & 4.43 \\
\hline Average Score & $\mathbf{3 . 6 9}$ & $\mathbf{0 . 6 3}$ \\
\hline
\end{tabular}

The respondents were aware that Eldoret Half Marathon is fully a Family Bank event $($ mean $=3.90)$, they understood the causes into which the funds raised from Eldoret Half Marathon are put in (mean = 3.84), Family Bank uses advertising and promotional activities to support the Marathon (mean=3.76), Family Bank comes to mind when they hear of the Eldoret Half Marathon (mean=3.75), Eldoret Half Marathon helps create brand awareness of Family Bank (mean=3.69), not sure that Eldoret Half Marathon helps increase the target market 
awareness (mean=3.59) and also that Family Bank displays the products and services they offer during the marathon (mean=3.31).

The study results indicate that Family Bank is recognized as the sole sponsor Eldoret half-marathon as a form of corporate social responsibility to members of the community they serve. This aspect of giving back to the community has enabled Family Bank to increase its customer's base in the region is it is deemed to support the most popular sports activities in the area.

The study results agree with Jordan and Tomalieh (2016) who carried out a study to establish the impact of events sponsorship on purchase intention of the attendees of the sponsored events and found out that brand awareness has a strong positive effect on the purchase intention of event attendees. In addition, the study agrees with Kipruto (2014) who carried out a study to find out the effect of corporate social responsibility on financial performance of commercial banks in Kenya. The study relied on secondary data over a five-year period spanning 2009 to 2013. Further, the study measured financial performance using earnings before taxes. The study used the actual spending on corporate social responsibility activities to measure expenditure on social activities.

Table 3: Customers' Brand Awareness of the Bank based on the Family Bank's Eldoret marathon

\begin{tabular}{|l|l|l|}
\hline & Mean & Std. Dev \\
\hline $\begin{array}{l}\text { The display of the banks logo during the marathon has enabled me to easily identify } \\
\text { the bank's corporate colors and logo }\end{array}$ & 3.90 & 0.18 \\
\hline $\begin{array}{l}\text { The involvement of Family Bank in the Eldoret Half Marathon has strengthened the } \\
\text { brand preference }\end{array}$ & 3.92 & 0.19 \\
\hline The bank explores new markets during the Marathon & 3.73 & 1.08 \\
\hline $\begin{array}{l}\text { Family Bank has strengthened its relations with existing customers due to its } \\
\text { involvement in the Marathon }\end{array}$ & 4.04 & 0.08 \\
\hline Total & $\mathbf{1 5 . 5 9}$ & $\mathbf{1 . 5 3}$ \\
\hline Average Score & $\mathbf{3 . 8 9}$ & $\mathbf{0 . 3 8}$ \\
\hline
\end{tabular}

Respondents agreed that Family Bank has strengthened its relations with its existing customers due to its involvement in Eldoret Half-Marathon (mean=4.04), Family Bank involvement in Eldoret Half-Marathon has strengthened its brand preference (mean=3.92), display of the Family Bank logo during the half-marathon has enabled them to easily identify Family Bank corporate colors and logo (mean=3.90), and that Family Bank explores new markets during Eldoret Half-Marathon (mean=3.73).

The study results obtained indicate that engaging in sports sponsorship is a very effective way of enhancing the brand image of an organization as its customers are convinced that the company is giving back some of its profit to the community that has helped the company to generate it. The study results agree with a study undertaken by Servaes and Tamayo (2013) who found out that if the level of awareness among the customers is low, then the effect of corporate sponsorship is in fact negative or at the very best, insignificant. This view is also consistent with Njambi (2012) who carried out a study to establish the effect of sponsorship of social activities at Kenya Airways. This case study analysis relied on both primary data and secondary data obtained from the company's financial statements. The findings indicated that the firm was actually involved in financing social activities with a focus on water, environment, health and education. The study employed content analysis in the analysis of the research data. It therefore failed to cover other types of companies particularly banks and the effect corporate sponsorship has on brand awareness.

\subsection{Sponsorship as a Method of Creating Brand Awareness to Other Methods}

Respondents indicated that sponsorship as a method of creating brand awareness unlike other methods such as conventional advertising and media promotions tends to positively impact lives of the people in the community, helps to give emotive connection that other methods don't, helps to create positive public relation and raise awareness of the organization as a whole, provide attractive content for organisations products and services, helps in building brand positioning through associative imagery, helps creating internal emotional commitment to the brand and also acts as corporate hospitality that promotes good relations with clients.

The study results conform to Deitz, Evans and Hansen (2013) whose study revealed that investors have a less negative perception of philanthropic sponsorships and sponsorships of events with distinctive values. Also, the study agrees with Njambi (2012) carried out a study to establish the effect of sponsorship of social activities at Kenya Airways. This case study analysis relied on both primary data and secondary data obtained from the company's financial statements. The findings indicated that the firm was actually involved in financing social activities with a focus on water, environment, health and education. The study employed content analysis in the analysis of the research data. It therefore failed to cover other types of companies particularly banks and the effect corporate sponsorship has on brand awareness. According to respondent four;

"With sponsorship, customers tend to be more aware of the brand since they are able to connect with the customers on one on one basis. This has helped improve customers' perception of our bank". 
Respondents indicated that by sponsoring Eldoret Half Marathon, Family Bank has benefited as it has increased its brand visibility since Family Bank logos are always displayed during the event, and also that it has helped the bank to generate higher return on investment. The study results agree with Jalleh, Donovan and Holman (2002) who conducted a study in Australia to establish the effectiveness of sponsorship activities with respect to brand awareness and brand attitude which established that sponsorship programs are very useful strategies in promoting brand awareness. In addition, the study conforms with results of a study undertaken by Kipruto (2014 to find out the effect of corporate social responsibility on financial performance of commercial banks in Kenya. The study relied on secondary data over a five-year period spanning 2009 to 2013. Further, the study measured financial performance using earnings before taxes. The study used the actual spending on corporate social responsibility activities to measure expenditure on social activities. The study relied on a descriptive survey and analyzed data using multiple linear regression of financial performance on corporate social expenditure. The findings indicated that expenditure on social activities had a positive effect on financial performance of commercial banks in Kenya.. According respondent three;

"Sponsoring the marathon has helped the bank to reconnect with our customers directly and also that it has helped to increase our reach and exposure to new customers who are normally happy that we sacrifice to sponsor this event every year".

Respondents indicated that the Eldoret Half Marathon has affected Family Bank in various ways. It improves Family Bank brand awareness and it allows for more customers to be recruited during the event, increases the publicity of Family Bank in the region and also allows the bank to have significant community support.

The study findings conform to Jordan and Tomalieh (2016) who carried out a study to establish the impact of events sponsorship on purchase intention of the attendees of the sponsored events and found out that brand awareness has a strong positive effect on the purchase intention of event attendees. The study disagrees with Brammer, Jackson and Matten (2012) who points out that there is a clash between business-driven and multistakeholder-driven approaches to corporate engagement in social activities.

This clash, in their view, is not only intra- national but also multi-national. In effect they contend that there is a paradoxical conflict between the liberal view of corporate social engagement and a confounding repercussion of the socially binding corporate responsibilities.

\subsection{Achieving Media Coverage of Marathon to Achieve Brand Awareness}

Respondents also indicated that Family Bank strives to achieve media coverage of the marathon in order to achieve brand awareness. Respondents five indicated that;

"We strive to achieve media coverage of the marathon through promotion, inviting both paid for and non-paid for media platforms, through engaging in long-term suitable relations with the media, as well as through sequence of events".

During Eldoret Half-Marathon, various media houses in Kenya are usually available to cover the event from the start to the end and also covered live on television for those being unable to attend to watch the event from their homes. The study results found out that respondents strongly agreed that Family Bank has strengthened its relations with its existing customers due to its involvement in Eldoret Half Marathon and also that involvement of Family Bank in the Eldoret Half Marathon has strengthened the brand preference. The study results agree with a study undertaken by Jordan and Tomalieh (2016) to establish the impacts of events sponsorship on purchase intention of the attendees of the sponsored events and found out that brand awareness has a strong positive effect on the purchase intention of event attendees.

\subsection{Summary and Conclusion}

Given the competitive environment in which organisations operate today, corporate reputation and image play the most important role in businesses' achieving their goals. Therefore, sponsorship especially in sports events is one of the means open to companies to bring their brands to the attention of consumers and present them in a favorable light for competitive advantage. Taking the greatest place in sponsorship activities sports sponsorship creates opportunities for organisations aiming to promote their products to large audiences in a short time. The study found out that Family Bank strives to achieve media coverage of the marathon in order to achieve brand awareness. On comparing sponsorship as a method of creating brand awareness with other methods, the study found out that sponsorship positively impact lives of the people in the community, helps to give emotive connection that conventional advertising doesn't, helps to create positive relations and raise awareness of the organisation as a whole, provide attractive content for organisations products and services, helps in building brand positioning through associative imagery, helps creating internal emotional commitment to the brand and also acts as corporate hospitality that promotes good relations with clients.

Recommendation: To streamline the effectiveness of sports sponsorship in promoting brand awareness, organizations may consider tapping upcoming talent in young marathon athletes and even extend to other races. 
This will increase the organizations customer base and also create brand awareness for new customers.

\section{References}

Akwensivie, D., Narteh, B., \& Iden, W. (2014). The Impact of Sponsorship Events on Consumer Based Brand Awareness Behaviors: Evidence from the Mobile Telecommunication Industry in Ghana. European Journal of Business and Management, 6(10), 107-120.

Amoako, G.K, Kwasi, D., Dzogbenuku, R.K. \& Kwesie, S.J. (2012). The effect of sponsorship on marketing communication performance: A case study of Airtel. African Journal of Marketing Management, 4(2), $65-$ 79, ISSN 2141-2421.

Brammer, S., Jackson, J. \& Matten, D. (2012). Corporate Social Responsibility and institutional theory: new perspectives on private governance. Socio-Economic Review, 10,(1) 3-28.

Central Bank of Kenya, CBK (2018). Directory of Commercial Banks and Mortgage Finance Companies. Nairobi: Central Bank of Kenya (CBK).

Cutlip, S.M. \& Center, A.H. (1952). Effective Public Relations. Englewood Cliffs, NJ:Prentice Hall.

Deitz, G.D., Evans, R.D. \& Hansen, J. (2013). Sponsorship and shareholder value: A re-examination and extension. Journal of Business Research, 66 (9), 1427-145.

Grunig, J.E. (1975). A multisystems theory of organizational communication. Communication Research, 2 (2), $99-136$

Grunig, J.E. (2006). Furnishing the Ediface: Ongoing Research on Public Relations as a Strategic Management Function. Journal of Public Relations Research 18, 151-76.

Image. International Journal of Business and Management; 11 (8), 162-175. ISSN 1833- Tomalieh, E.F. (2016). The Impact of Events Sponsorship on Attendee's Purchase Intention: The Mediating Role of Brand 385.

Jalleh, G., Donovan, R.J. \& Holman, C.D. (2002). Sponsorship: Impact on Brand Awareness and Brand Attitudes. Social Marketing Quarterly, 8, 35-45.

Kevin, L. K. (2013). Strategic Brand Management (4th ed.). Upper Saddle River, NJ: Pearson Prentice-Hall.

Kipruto, D. (2014). The Effect of Corporate Social Responsibility on Financial Performance of Commercial Banks in Kenya .Research Project in Partial Fulfilment of the Requirements for the Award of Master of Science in Finance, University Of Nairobi.

KPMG International (2013) The KPMG Survey of Corporate Responsibility Reporting

Lawler, E. J. \& Thye, S. R. (1999). Bringing Emotions into Social Exchange Theory. Annual Review of Sociology. 25: 217-244.

L'Etang, J. (2013). Public Relations: A Discipline in Transformation. Sociology Compass, 7 (10), 799-81

McDonell, J.; Strom-Gottfried, K. J.; Burton, D. L.; Yaffe, J. (2006). Behaviorism, Social Learning, and Exchange Theory. Contemporary human behavior theory: a critical perspective for social work. Pearson. 349-85

Makungu, 1. (2014). Effects of sports sponsorship on performance of Kenyan firms involved in sports. Research Project for Master of Business Administration Degree, Kabarak University.

Mugenda, M and Mugenda, G. (1999). Research Methods: Qualitative and Quantitative Approaches. Nairobi: Acts Press

Ng'etich, H. (2016). Factors Influencing the Adoption of Sports Sponsorship as a Marketing Tool by Kenyan Firms in the Telecommunication Industry. A Research Project Submitted for ward of Master of Business Administration Degree, University Of Nairobi.

Njambi, R. H. (2012). Corporate Social Responsibility Practices in Kenya Airways. A Research Project Submitted in Partial Fulfillment of the Requirements for the Award of Master of Business Administration Degree, University of Nairobi.

Pickton, D. \& Broderick, A. (2005). Integrated Marketing Communications (2 ${ }^{\text {nd }}$ Ed.). Pearson Education, Financial Times Prentice Hall, ISBN 0273676458.

PricewaterhouseCoopers (2010). Back on track: The outlook for the global sports market to 2013. Retrieved March 22, 2018, from http://www.pwc.com/gx/en/entertainment-media/publications/outlook-globalsportsmarket-2013.jhtml.

Reiser, M. (2012). The sponsorship effect: Do sport sponsorship announcements? Dissertation thesis, German Sport University Cologne.

Reiser, M., Breuer, C. \& Wicker, P. (2012). The Sponsorship Effect: Do Sport Sponsorship Announcements Impact the Firm Value of Sponsoring Firms? International Journal of Sport Finance, 2012, 7, 232-248.

Saunders, M., Lewis, P. \& Thornhill, A. (2012). Research methods for business students. Harlow, England: Prentice Hall.

Schivinski, B. \& Dabrowski, D. (2016). Effect of Social Media Communication on Consumer Perceptions of Brands. Journal of Marketing Communications, 22(2), 189-214.

Servaes, H. \& Tamayo, A. (2012). The Impact of Corporate Social Responsibility on Firm Value: The Role of 
Customer Awareness. Management Science, 13 (2). 67-83.

Spais, G. S \& Johnston, M.A. (2014). The Evolution of Scholarly Research on Sponsorship: Expectations About the Future of This Research Domain, Journal of Promotion Management, 20:3, 267-290.

USAID (2015). Health-Related Corporate Social Responsibility in Africa: A Multicountry Study. African Strategies for Health. http://www.africanstrategies4health.org

Yamane, Taro. 1967. Statistics, An Introductory Analysis, 2nd Ed., New York: Harper and Row 